\title{
Soilborne Pathogens of Cereals in an Irrigated Cropping System: Effects of Tillage, Residue Management, and Crop Rotation
}

\author{
T. C. Paulitz and K. L. Schroeder, USDA-ARS, Root Disease and Biological Control Research Unit, Pullman, WA \\ 99164-6430; and W. F. Schillinger, Department of Crop and Soil Sciences, Washington State University, Dryland \\ Research Station, Lind, WA 99341
}

\begin{abstract}
Paulitz, T. C., Schroeder, K. L., and Schillinger, W. F. 2010. Soilborne pathogens of cereals in an irrigated cropping system: Effects of tillage, residue management, and crop rotation. Plant Dis. 94:61-68.

An irrigated cropping systems experiment was conducted for 6 years in east-central Washington State to examine agronomic and economic alternatives to continuous annual winter wheat (Triticum aestivum) with burning and plowing, and to determine how root diseases of cereals are influenced by management practices. The continuous winter wheat treatment with burning and plowing was compared with a 3-year no-till rotation of winter wheat-spring barley (Hordeum vulgare)-winter canola (Brassica napus) and three straw management treatments: burning, straw removal, and leaving the straw stubble standing after harvest. Take-all disease and inoculum increased from years 1 to 4 in the continuous winter wheat treatment with burning and plowing, reducing plant growth compared to the no-till treatments with crop rotations. Inoculum of Rhizoctonia solani AG-8 was significantly lower in the tilled treatment compared to the no-till treatments. Inoculum concentration of Fusarium pseudograminearum was higher than that of $F$. culmorum, and in one of three years, the former was higher in treatments with standing stubble and mechanical straw removal compared to burned treatments. Residue management method had no effect on Rhizoctonia inoculum, but spring barley had more crown roots and tillers and greater height with stubble burning. This 6-year study showed that irrigated winter wheat can be produced in a no-till rotation without major disease losses and demonstrated how cropping practices influence the dynamics of soilborne cereal diseases and inoculum over time.
\end{abstract}

Irrigated crops are produced on 645,000 ha in east-central Washington and northcentral Oregon (1). Approximately $70 \%$ of this cropland is irrigated with water diverted from rivers, while water for the remaining hectares is pumped from deep wells. Much of the irrigated cropland is found in areas of less than $200 \mathrm{~mm}$ annual precipitation, where dryland farming is difficult or impossible. Wind erosion is the biggest environmental concern throughout the region $(21,31)$.

Major irrigated field crops include potatoes (Solanum tuberosum L.), corn (Zea mays L.), wheat (Triticum aestivum L.), barley (Hordeum vulgare L.), oat (Avena sativa L.), alfalfa (Medicago sativa L.), and dry bean (Phaseolus vulgaris L.). Winter canola (Brassica napus L.) is not yet widely grown but has received increased

Corresponding author: T. C. Paulitz

E-mail: paulitz@wsu.edu

Mention of product and equipment names does not imply endorsement.

Accepted for publication 24 August 2009.

doi:10.1094/PDIS-94-1-0061

This article is in the public domain and not copyrightable. It may be freely reprinted with customary crediting of the source. The American Phytopathological Society, 2010. attention in recent years due to its reported benefits for subsequent crops in the rotation (10). Due to many available crop options, there are no "set" cropping systems. Farmers rotate crops to reduce pests and diseases, optimize water use, and take advantage of current market opportunities.

Many deep-well irrigators plant winter wheat on the same field every year. Irrigated wheat grain yields range from 6,000 to $9,400 \mathrm{~kg} / \mathrm{ha}$ with residue production of $11,000 \mathrm{~kg} / \mathrm{ha}$ or more. After grain harvest in August, the traditional practice is to burn the stubble and invert the surface soil with moldboard plow tillage in preparation for planting in September. Generally, farmers feel they need to burn their fields because high residue levels hamper planting and to control the problematic grass weed, downy brome (Bromus tectorum L.). Alternatives to field burning are needed to reduce smoke emissions and maintain air quality. Therefore, new crop rotation and stubble management strategies are needed to make no-till (without burning) work.

A group of deep-well irrigated wheat farmers approached Washington State University (WSU) and USDA-ARS scientists in 1998 concerning the future of their farming operations. The farmers were concerned about potential regulations to reduce or eliminate cereal stubble burning and desired research on how to farm profitably without field burning. Reduction or elimination of tillage could also reduce soil erosion. The experiment reported here was designed jointly by farmer advisors and WSU and USDA-ARS scientists. The experiment involved both crop rotation and stubble management factors.

The objective of the experiment was to determine the feasibility of planting directly into high levels of residue (no-till) as a substitute for burning in irrigated cropping systems. Specific objectives of the larger project were to:

1. Test a 3-year crop rotation of winter wheat-spring barley-winter canola directly planted (no-till) (i) into standing stubble, (ii) after mechanical removal of stubble, and (iii) after burning the stubble. This was compared with the check treatment of annual winter wheat planted after stubble burning + moldboard plowing.

2. Evaluate and develop effective techniques for planting crops into heavy surface stubble using no-till methods.

3. Document cumulative effects of a diverse no-till crop rotation under three stubble management practices on diseases, soil physical and biological properties, water use efficiency, weed ecology, and farm economics, and to compare these effects to those under the check treatment.

The experiments reported here were part of objectives 1 and 3 , and were designed to answer several root disease questions: (i) Will root diseases increase when tillage is eliminated? Previous work has shown that Rhizoctonia root rot and bare patch can increase in no-till rotations $(17,24,27)$. (ii) Will residue management reduce disease severity? Gaeumannomyces graminis var. tritici (causal agent of take-all) and Fusarium pseudograminearum and $F$. culmorum (causal agents of Fusarium crown rot) survive in crown tissue, and several studies have shown increases in diseases in no-till systems where residue is left on the surface $(2,32)$. In addition, irrigated winter wheat produces more residue compared to dryland winter wheat, as 1.3 to $2.0 \mathrm{~kg}$ of straw is produced for every $1.0 \mathrm{~kg}$ grain (9). (iii) Will crop rotation reduce root diseases? Take-all can be controlled by rotating with broadleaf crops such as canola or pea (Pisum sativum L.), which are resistant to take-all (12), but Rhizoctonia solani AG-8 (cause of Rhizoctonia root rot and bare patch) has a broad host range, and 
crop rotation does not reduce bare-patch (7). In this paper, we report on soilborne pathogens and root diseases in these cropping systems, specifically Rhizoctonia root rot and bare patch, take-all, Fusarium crown rot (35), and lesion nematodes (Pratylenchus neglectus and P. thornei).

\section{MATERIALS AND METHODS}

Experiment layout and treatments. A 6-year irrigated cropping study was conducted at the WSU Dryland Research Station near Lind during the 2001 to 2006 crop years. The experimental area had been in a 2-year cultivated dryland winter wheat-summer fallow rotation for at least 30 years prior to initiation of the experiment. To obtain uniform residue levels at the beginning of the experiment, the entire 4-ha experimental area was planted to 'Madsen' winter wheat in September 1999. The irrigated grain yield in August 2000 was $7,400 \mathrm{~kg} / \mathrm{ha}$, and straw production was $11,000 \mathrm{~kg} / \mathrm{ha}$. Beginning in the $2001 \mathrm{crop}$ year, a 3-year crop rotation of winter wheat-spring barley-canola was practiced under the three stubble management methods. These were planted: (i) directly into standing stubble, (ii) after removal of stubble by swathing and baling of the straw, or (iii) after burning the stubble. All no-till one pass with a low disturbance Cross Slot no-till drill (3). A check treatment of continuous annual winter wheat sown with a conventional double-disc drill after stubble treatments were planted and fertilized in

burning and moldboard plowing was also included. The experimental design was a split block with four replications. Main plots $(15 \times 150 \mathrm{~m})$ were crops and subplots $(15 \times 50 \mathrm{~m})$ were residue management. Crops were planted perpendicular to the residue management treatments. Each portion of the 3-year no-till crop rotation in each residue management method was sown each year. Thus, there were 40 plots ( 3 crops $\times 3$ residue management practices $\times 4$ replications $=36$ plots +4 replications of the check treatment of continuous winter wheat after burning and plowing). The burn and plow check plots were $15 \times 150$ $m$ in size.

The timing of irrigation varied from year to year, but the entire experiment received $380 \mathrm{~mm}$ of irrigation water every year with $150 \mathrm{~mm}$ applied in the fall and $230 \mathrm{~mm}$ applied in the spring. Water was applied via hand-line sprinklers, and the same irrigation timing was used for all crops. Average annual precipitation at the site during the 6-year study period was 221 $\mathrm{mm}$.

All treatments received $190 \mathrm{~kg} \mathrm{~N}, 34 \mathrm{~kg}$ $\mathrm{P}$, and $22 \mathrm{~kg} \mathrm{~S}$ per hectare each year. Soils at the site contain adequate potassium (K) for crop production with extractable soil $\mathrm{K}$ levels $>450 \mathrm{~kg} / \mathrm{ha}$. The burn-plow continuous winter wheat received all fertilizer in granular form with $135 \mathrm{~kg} \mathrm{~N}, 34 \mathrm{~kg} \mathrm{P}$, and $22 \mathrm{~kg} \mathrm{~S}$ per hectare applied with a granular spreader in September prior to plowing and planting. The sources that

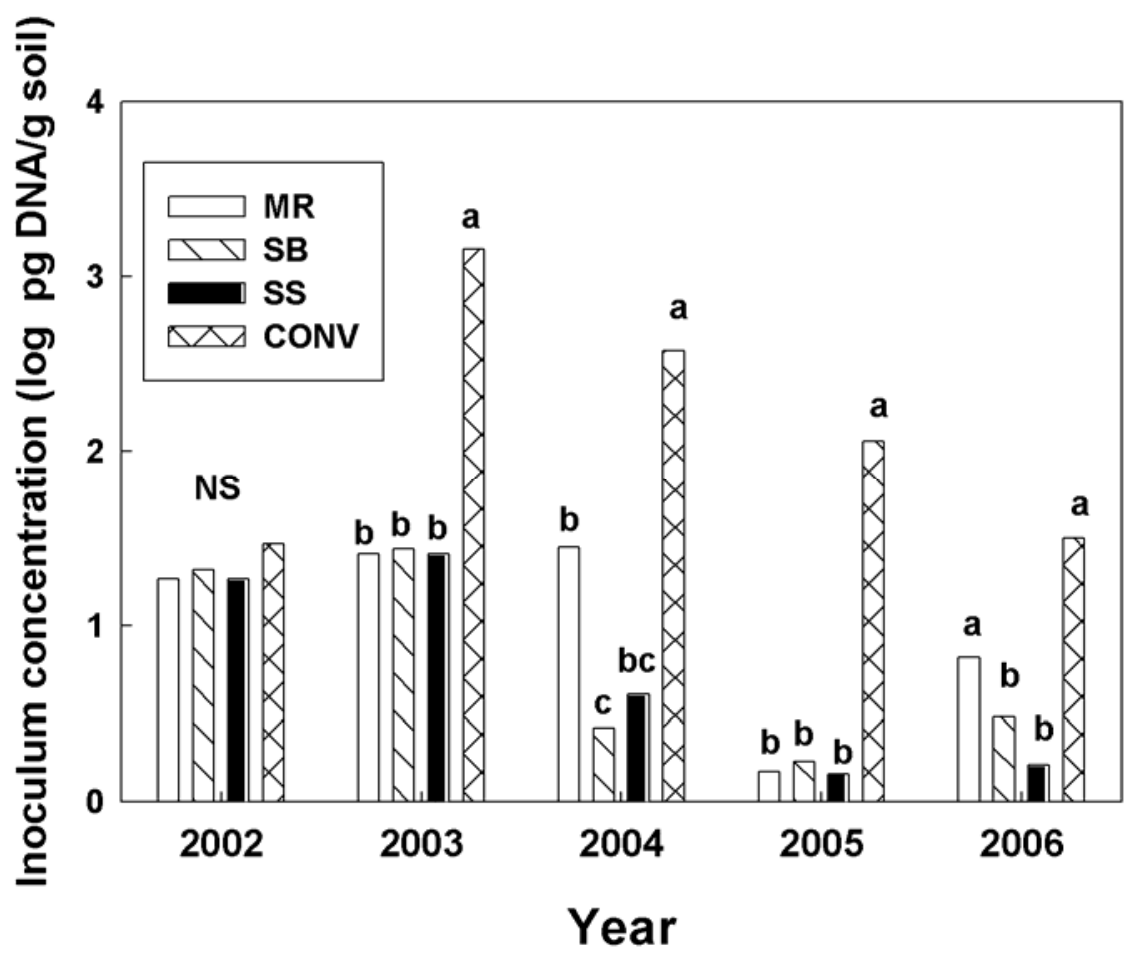

Fig. 1. DNA concentration of Gaeumannomyces graminis var. tritici in March-April in soil of a winter wheat crop grown in four crop rotation/residue management treatments: winter wheat-spring barleycanola no-till rotation with mechanical stubble removal (MR), stubble burning (SB), or stubble left standing (SS), and continuous winter wheat with stubble burned and moldboard plowed (CONV). Treatments within each year with the same letters are not statistically different, $P=0.05$, Tukey's mean separation test. made up this mix were urea, monoammonium phosphate, and ammonium sulfate. The additional $55 \mathrm{~kg} / \mathrm{ha} \mathrm{N}$ was applied as granular urea top-dress to the growing wheat crop in April. The no-till winter wheat received $135 \mathrm{~kg} \mathrm{~N}, 34 \mathrm{~kg}$, and 22 $\mathrm{kg} \mathrm{S}$ per hectare as liquid at time of planting with the Cross Slot no-till drill. The liquid fertilizer mix was Solution 32 $\left(\mathrm{NH}_{4} \mathrm{NO}_{3}+\right.$ urea $)+$ ammonium phosphate + thiosul. The additional $55 \mathrm{~kg} / \mathrm{ha} \mathrm{N}$ was applied as a granular urea top-dress to the growing wheat crop in April. Winter canola received the same fertilizer regime as the no-till winter wheat. However, winter canola was killed by cold and/or disease in 5 out of 6 years; therefore, $55 \mathrm{~kg} / \mathrm{ha}$ of liquid Solution $32 \mathrm{~N}$ was applied at planting of spring canola in those 5 years. Spring barley received $190 \mathrm{~kg} \mathrm{~N}, 34 \mathrm{~kg}$, and $22 \mathrm{~kg} \mathrm{~S}$ per hectare as Solution $32+$ ammonium phosphate + thiosul at time of planting applied with the Cross Slot no-till drill.

Winter wheat (cv. Madsen) and spring barley (cv. Baronesse) were sown at a rate of $112 \mathrm{~kg} / \mathrm{ha}$ during all years. Winter canola and spring canola sowing rates varied from 4 to $8 \mathrm{~kg} / \mathrm{ha}$ and averaged $5.6 \mathrm{~kg} / \mathrm{ha}$ over the 6 years. Additional details on field operations and inputs for production of winter wheat, spring barley, and canola in the no-till rotation and for continuous winter wheat after burning and plowing are reported by Schillinger et al. (29) and Zaikin et al. (41).

Pathogen quantification from fungal DNA from soil. In March or April, three shovels of soil were randomly taken from each replicate block of each treatment, and the soil within each replicate was combined. One kilogram of soil from each sample was air-dried and frozen at $-20^{\circ} \mathrm{C}$ for 2 weeks prior to sending to the South Australia Research and Development Institute (SARDI), Adelaide, SA. SARDI developed a suite of tests for the quantification of six fungal pathogens and three nematode pathogens of wheat (20). This system has been used commercially (over 16,000 samples processed) in the Australian grain belt for over a decade (20) and can help growers predict the risk of disease and select appropriate management strategies. DNA was extracted from the soil and quantified according to the methods of Ophel-Keller et al. (20). DNA of tested fungal and nematode pathogens was reported as pg/g soil. For statistical analysis, DNA concentrations were log transformed to maintain normality for the ANOVA analysis.

Plant and disease measurements. Each year, approximately in mid-April for winter wheat and mid-May for spring barley, three samples were taken within each plot approximately $15 \mathrm{~m}$ apart along a transect in the center of the plot. A sample consisted of a shovelful within the row, with approximately five plants in each sample. 
Plants were kept at $4^{\circ} \mathrm{C}$ until evaluation. Three plants were randomly chosen from each sample, for a total of nine plants per replicate. Roots were washed, and the number of tillers, plant height, length of first true leaf, number of seminal and number of crown roots were recorded. The number of roots with typical Rhizoctonia root rot symptoms (spear-tipping, constricted cortex, brown root tips) were counted, and incidence was expressed as the percentage of seminal or crown roots that were diseased. Disease severity was also rated using a 0 to 8 scale (16). Takeall severity was measured on winter wheat using a 0 to 5 scale (19).

Grain yield was obtained in late July or early August by harvesting a 50-m-long swath through each plot with a plot combine with a 1.5 -m-wide cutting platform operated $20 \mathrm{~cm}$ above the ground. The plot combine was equipped with a custom-built blowing air system to uniformly distribute straw and chaff (28). Immediately thereafter, a commercial combine equipped with a straw chopper and chaff spreader was used to harvest the entire experimental area, cutting slightly lower than $20 \mathrm{~cm}$ above the ground.

Statistical analysis. Analysis of variance was performed on all transformed DNA data and plant parameters, with year, residue/tillage treatment, and block as main effects. Means were separated with Tukey's test. For the disease ratings, data were analyzed with ordinal logistic analysis, and means were separated with the non-parametric Kruskal-Wallis test. Analyses were performed with JMP 4.0 (SAS Institute, Cary, NC).

\section{RESULTS}

Pathogen quantification from fungal DNA from soil. For the take-all pathogen $G$. graminis var. tritici, the year $\times$ treatment interaction was significant $(P<$ 0.001). In the first year that DNA was measured, there was no significant treatment effect (Fig. 1). However, in the following year, continuous winter wheat had significantly higher DNA levels than in the winter wheat treatments with rotation crops. This difference was present in the three subsequent crop years, although the level of G. graminis var. tritici in the continuous winter wheat treatment declined over time.

The DNA concentrations of $R$. solani AG-8 were significantly affected by both year $(P<0.001)$ and residue treatment $(P$ $<0.001)$, but there was no significant year $\times$ treatment interaction $(P=0.13)$. Averaged over all years, continuous winter wheat had significantly less DNA of Rhizoctonia (1.31 log pg DNA/g) compared to the mechanical removal (2.00), stubble burned (2.18), and standing stubble (2.09) treatments (Fig. 2).

F. pseudograminearum DNA concentrations in winter wheat were affected by residue treatment $(P=0.002)$ and year $(P$ $=0.012)$, and there was no significant treatment $\times$ year interaction $(P=0.08)$. Averaged over all years, significantly higher concentrations of DNA were found in the mechanical removal and standing stubble treatment compared to the conventional and burned treatment (Fig. 3). F.

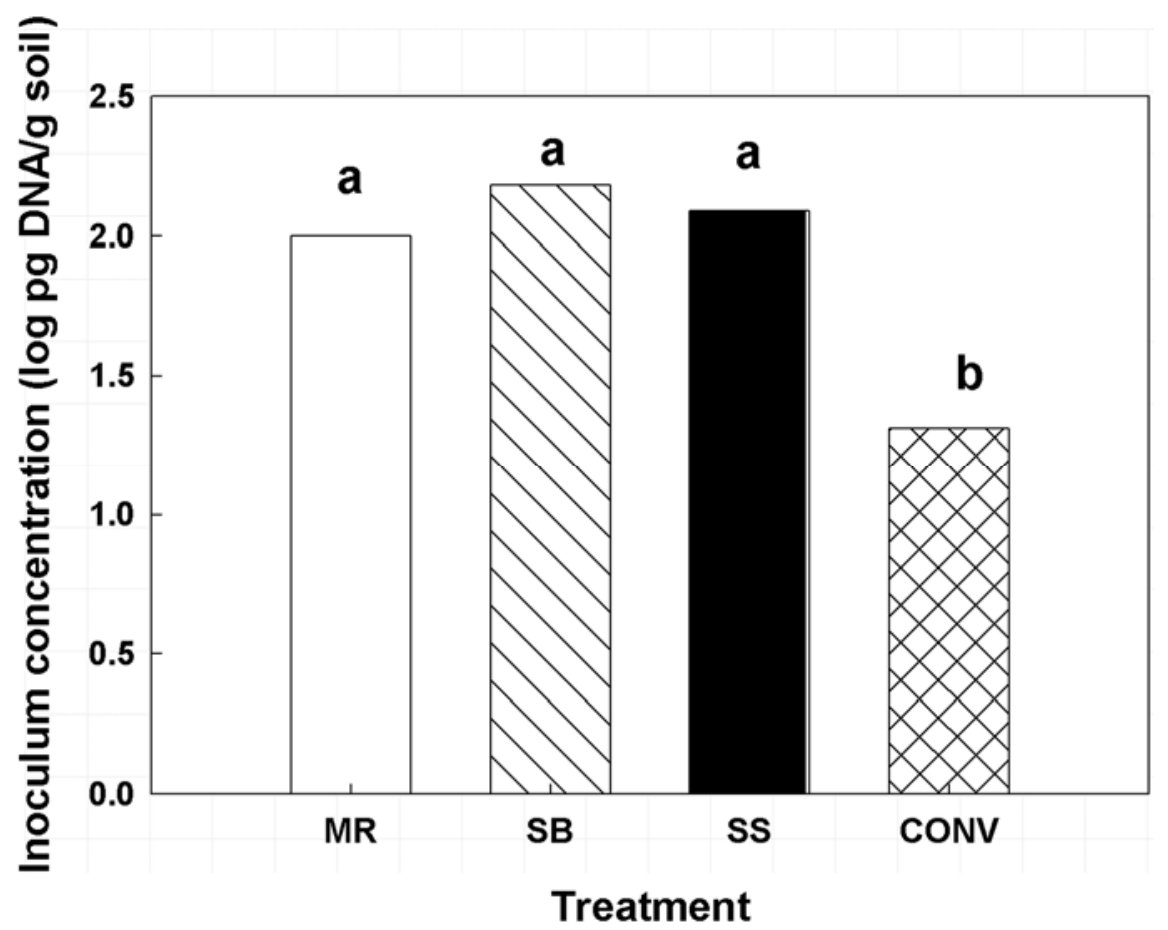

Fig. 2. DNA concentration of Rhizoctonia solani AG-8 in March-April in soil of a winter wheat crop grown in four crop rotation/residue management treatments averaged across all years: winter wheat-spring barleycanola no-till rotation with mechanical stubble removal (MR), stubble burning (SB), or stubble left standing (SS), and continuous winter wheat with stubble burned and moldboard plowed (CONV). Treatments with the same letters are not statistically different, $P=0.05$, Tukey's mean separation test.

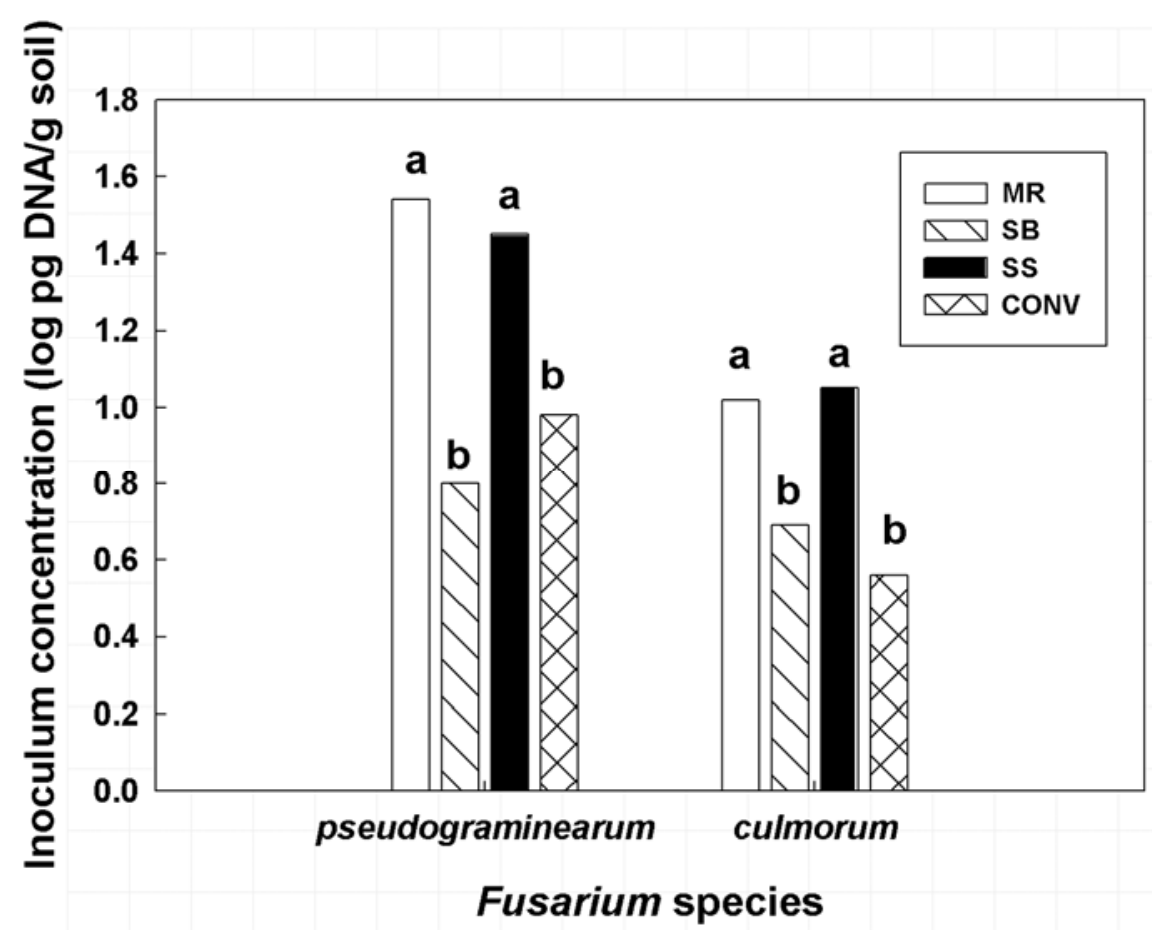

Fig. 3. DNA concentration of Fusarium pseudograminearum and F. culmorum in March-April in soil of a winter wheat crop grown in four crop rotation/residue management treatments averaged across all years: winter wheat-spring barley-canola no-till rotation with mechanical stubble removal (MR), stubble burning (SB), or stubble left standing (SS), and continuous winter wheat with stubble burned and moldboard plowed (CONV). Treatments within each Fusarium species with the same letters are not statistically different, $P=0.05$, Tukey's mean separation test. 
culmorum showed similar trends (Fig. 3), although the overall DNA concentrations of F. culmorum were lower than those of $F$. pseudograminearum.

The DNA levels of $P$. neglectus in winter wheat had a significant treatment $\times$ year interaction $(P=0.005)$. In 2 years $(2002$ and 2005), there was no treatment effect (Fig. 4). However, in the other 3 years, significantly higher levels were found in the continuous winter wheat treatment with burning and plowing, compared to the

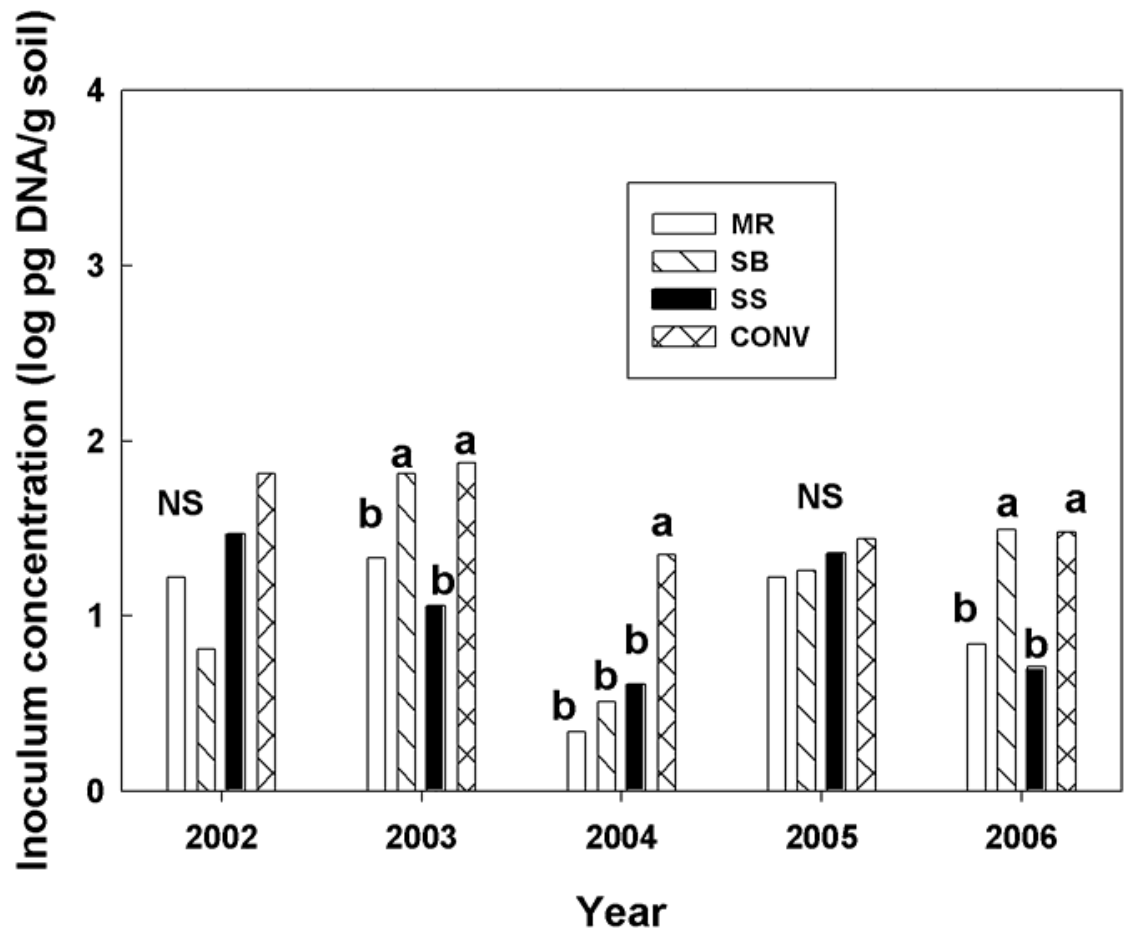

Fig. 4. DNA concentration of Pratylenchus neglectus in March-April in soil of a winter wheat crop grown in four crop rotation/residue management treatments: winter wheat-spring barley-canola no-till rotation with mechanical stubble removal (MR), stubble burning (SB), or stubble left standing (SS), and continuous winter wheat with stubble burned and moldboard plowed (CONV). Treatments within each year with the same letters are not statistically different, $P=0.05$, Tukey's mean separation test.

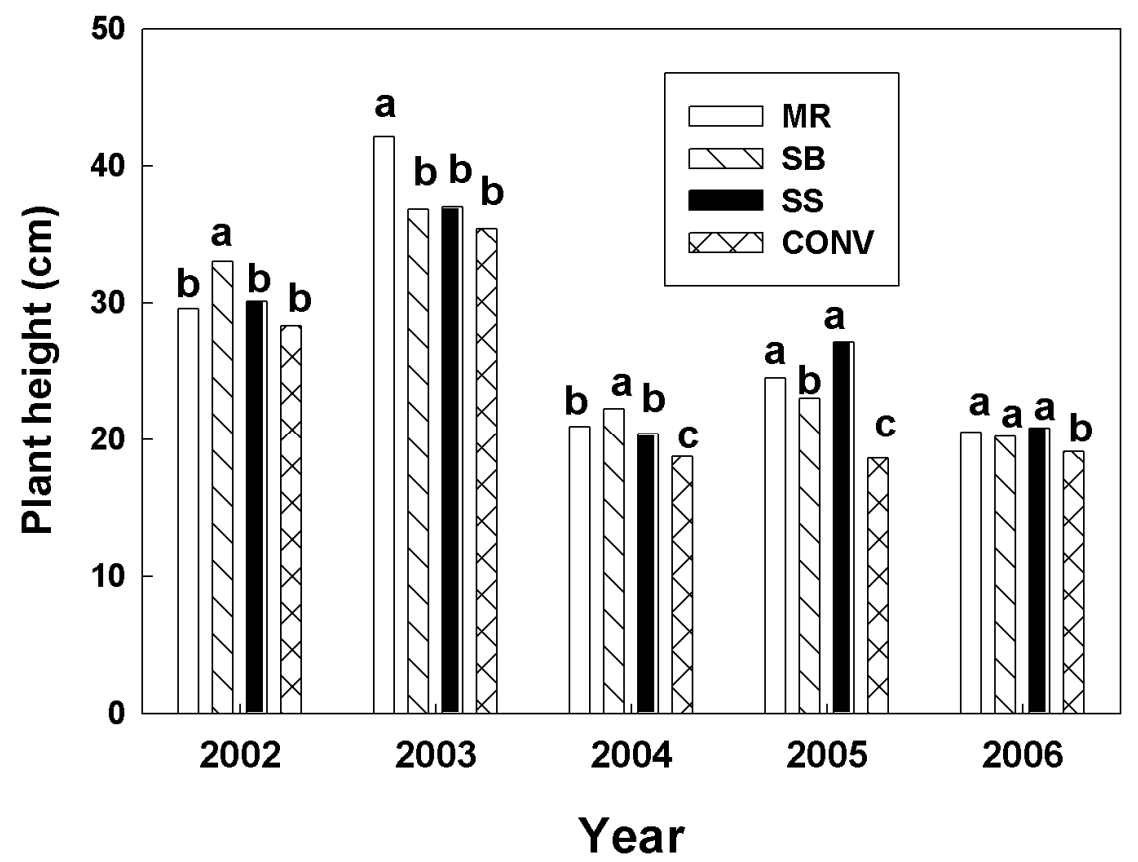

Fig. 5. Plant height of winter wheat seedlings in April grown in four crop rotation/residue management treatments: winter wheat-spring barley-canola no-till rotation with mechanical stubble removal (MR), stubble burning (SB), or stubble left standing (SS), and continuous winter wheat with stubble burned and moldboard plowed (CONV). Treatments within each year with the same letters are not statistically different, $P=0.05$, Tukey's mean separation test. no-till treatments with standing stubble or mechanical stubble removal. The DNA of P. thornei was below the detection limit.

Plant parameters. Both tiller number and plant height of winter wheat were affected by residue treatment and interacted with year $(P=0.05$ and $<0.001$, respectively). The continuous winter wheat with burning and plowing had the shortest plants in 2004, 2005, and 2006 (Fig. 5). In 2003 and 2004, the continuous winter wheat with burning and plowing and the no-till wheat with standing stubble had fewer tillers than the other treatments (Fig. 6). Averaged over all years, fewer seminal roots were present in the continuous winter wheat, and fewer crown roots in the standing stubble treatment (data not shown).

Both plant height and tiller number of spring barley plants were affected by residue treatment $(P<0.001)$ and interacted with year $(P<0.006$ and 0.0001 , respectively). In general, the stubble burned treatment had the tallest plants with the greatest number of tillers (Figs. 7 and 8). Barley grown with the stubble burned treatment also had the greatest number of crown roots in 2003, 2004, and 2005 (Fig. 9).

Disease measurements. The highest take-all severity ratings on wheat were found in the continuous winter wheat with burning and plowing, where ratings were two to three units higher than in the diversified no-till rotation treatments (29). Takeall in the continuous wheat treatment increased from 2002 to 2004 , and then declined in 2006. In 2003 the take-all rating was 3.8, but in 2006 it was only 2.0.

The percentage of wheat crown roots and seminal roots exhibiting symptoms of Rhizoctonia root rot was variable across years $(P<0.0001)$, and year interacted with treatment $(P<0.001$ and 0.0001 , respectively, Figs. 10 and 11). In 2003 and 2006, the continuous winter wheat had the lowest level of crown and seminal root infection symptoms compared to the other treatments. The continuous winter wheat treatment also had the lowest Rhizoctonia root rot rating in 2003 and 2006 (Fig. 12).

The method of residue management had no effect on the incidence of Rhizoctonia root rot on barley crown roots, and the effect on seminal roots was variable. The stubble burned treatment had numerically the lowest disease level in 2003, 2004, and 2005. Rhizoctonia root rot rating was also variable across years. In 2002, 2003, and 2004, method of residue management had no effect. But in 2005, the stubble burned treatment had the lowest rating $(2.5$ compared to 4.4 in the mechanical removal treatment and 3.7 in the standing stubble treatment), while in 2006, the standing stubble had the lowest rating (2.6 compared to 3.8 in the mechanical removal treatment and 3.1 in the stubble burned treatment). 


\section{DISCUSSION}

Statistically significant year $\times$ treatment interactions for almost all of the variables measured suggest that variable environmental conditions each year play a strong role in disease expression. Another explanation is that disease and inoculum dynamics change over the course of a cropping system or rotation (29). For example, takeall increased over time in the continuous winter wheat treatment, and burning and plowing did not reduce this disease over the first 4 years of the rotation. This was verified by higher levels of G. graminis var. tritici DNA detected in the soil, which was accompanied by increased disease, significantly shorter plants with fewer tillers, and significantly less grain yield $(29,41)$ compared to no-till winter wheat in a 3-year rotation with barley and canola. The effect of crop rotation on reducing $G$. graminis var. tritici is well documented (12). Broadleaf crops such as canola are not hosts for G. graminis var. tritici, and although this pathogen will infect barley, less disease and inoculum are produced (8). To our knowledge, this is the first demonstration of the dynamics of inoculum increase of $G$. graminis var. tritici during the first few years of monocropping, using DNA-based techniques. We also observed take-all decline after 4 to 5 years of monocropping (29). This phenomenon, documented around the world, is characterized as a reduction in disease after a few years of disease increase in monoculture wheat (11) and is caused by increased populations of antagonistic Pseudomonas spp. that produce antifungal compounds such as 2,4-diacetylphloroglucinol and phenazine in the G. graminis var. tritici lesions on the root and in the rhizosphere (39). Take-all decline was first observed at the WSU Dryland Research Station at Lind in the late 1970s by Cook et al. (4). Take-all decline was correlated with high levels of 2,4-diacetylphloroglucinol producers at this location $(18,25,26)$. We also detected high levels of 2,4-diacetylphloroglucinol producers in the continuous winter wheat with burning and plowing treatment (R. Allende-Molar, unpublished).

The only consistent effect of residue management method on plant growth of winter wheat and spring barley was fewer crown roots on wheat in the standing stubble treatment. This could be due to cooler soil temperatures from the mulching effect of the stubble and the retention of more soil moisture in the spring. Schroeder and Paulitz (30) observed a similar effect in wheat, comparing no-till to conventionally planted (i.e., after tillage) wheat. The number of tillers and plant height of barley were significantly highest in the stubble burned treatment. The development and heading of barley was also accelerated in this treatment, where flowering occurred about 1 week earlier than in the other treatments (data not shown). This effect is likely due to faster soil warming because of the lack of residue and the darker soil surface (5).

Another major pathogen in this region is $R$. solani AG-8, which causes root rot, stunting, and bare patch. The continuous winter wheat with burning and plowing had lower levels of Rhizoctonia in the soil, compared to the no-till treatments. The reduction of Rhizoctonia with tillage has been well documented in the Pacific
Northwest of the United States and in Australia $(17,24,27,38)$. The concentration of Rhizoctonia DNA in no-till soil was approximately $1 \log$ unit higher than in the burn and plow treatment. The real comparison would have been with a healthy crop in the continuous annual burn and plow winter wheat that was not infected with the take-all pathogen.

Among residue management treatments, there was no consistent effect on Rhizocto-

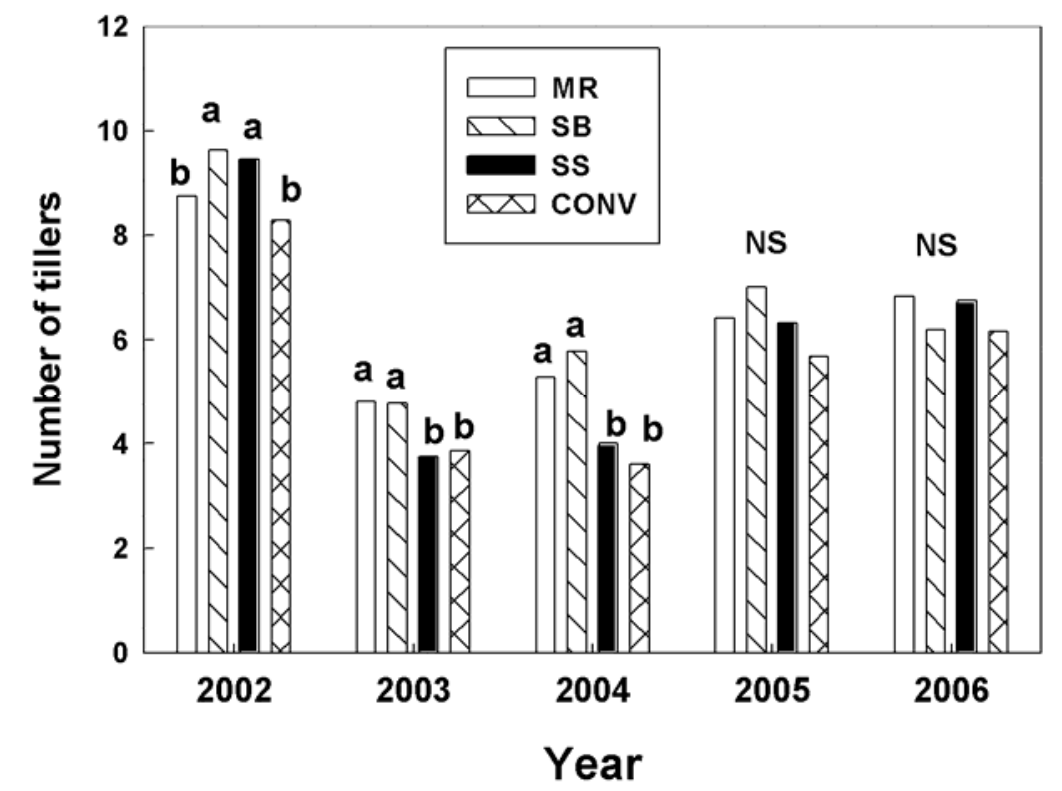

Fig. 6. Number of tillers of winter wheat seedlings in April grown in four crop rotation/residue management treatments: winter wheat-spring barley-canola no-till rotation with mechanical stubble removal (MR), stubble burning (SB), or stubble left standing (SS), and continuous winter wheat with stubble burned and moldboard plowed $(\mathrm{CONV})$. Treatments within each year with the same letters are not statistically different, $P=0.05$, Tukey's mean separation test.

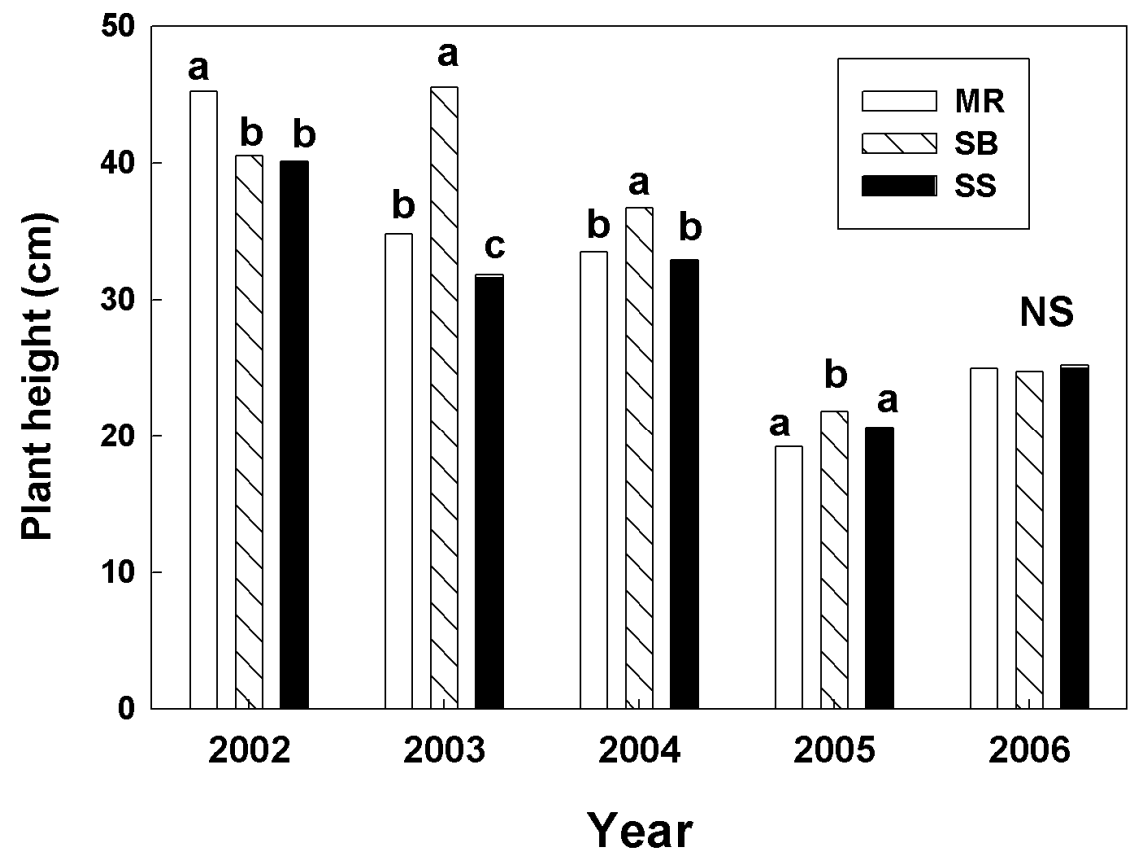

Fig. 7. Plant height of spring barley seedlings in May grown in three crop rotation/residue management treatments: winter wheat-spring barley-canola no-till rotation with mechanical stubble removal (MR), stubble burning (SB), or stubble left standing (SS). Treatments within each year with the same letters are not statistically different, $P=0.05$, Tukey's mean separation test. 


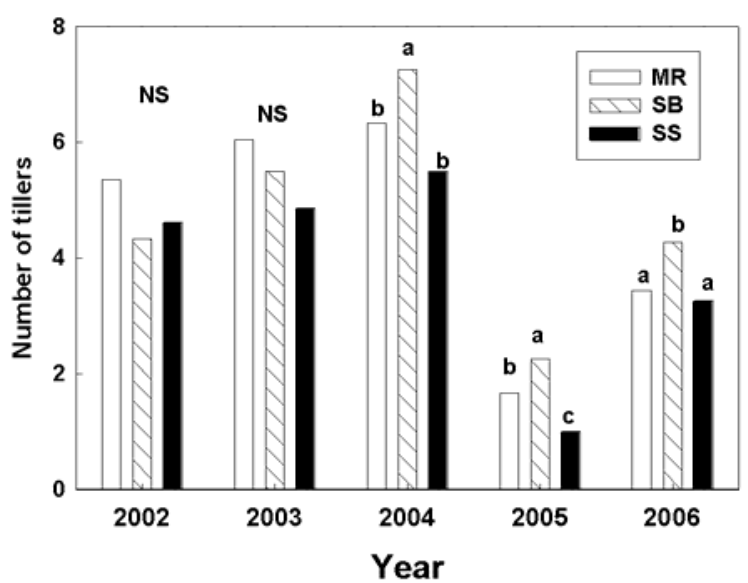

Fig. 8. Number of tillers of spring barley seedlings in May grown in three crop rotation/residue management treatments: winter wheat-spring barley-canola no-till rotation with mechanical stubble removal (MR), stubble burning (SB), or stubble left standing (SS). Treatments within each year with the same letters are not statistically different, $P=0.05$, Tukey's mean separation test.

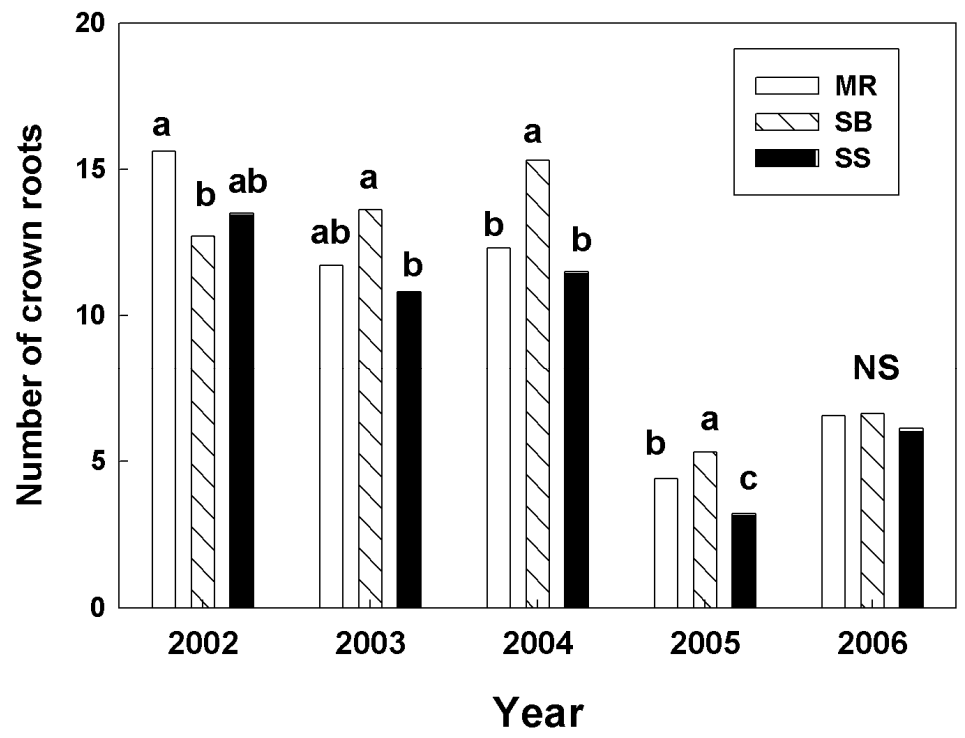

Fig. 9. Number of crown roots of spring barley seedlings in May grown in three crop rotation/residue management treatments: winter wheat-spring barley-canola no-till rotation with mechanical stubble removal (MR), stubble burning (SB), or stubble left standing (SS). Treatments within each year with the same letters are not statistically different, $P=0.05$, Tukey's mean separation test.

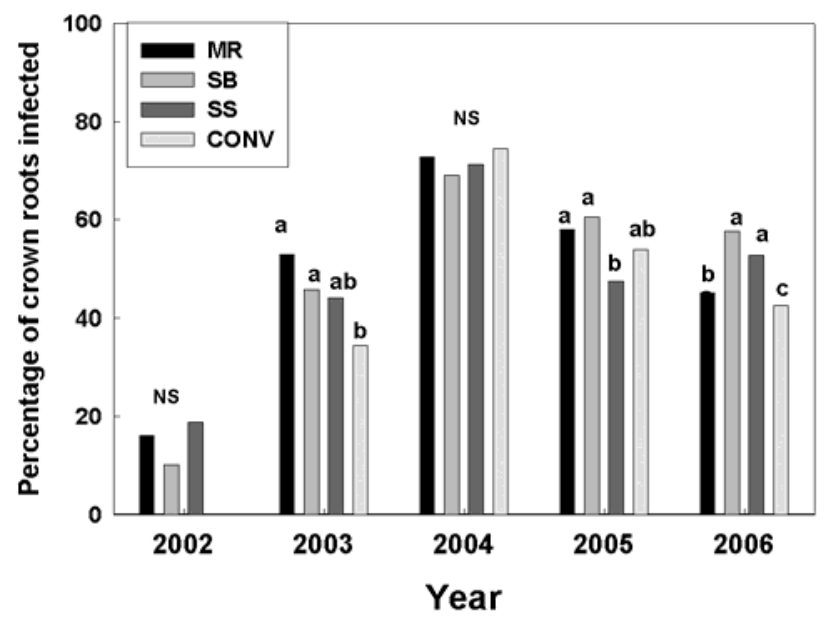

Fig. 10. Percentage of crown roots with symptoms of Rhizoctonia in winter wheat seedlings in April grown in four crop rotation/residue management treatments: winter wheat-spring barley-canola no-till rotation with mechanical stubble removal (MR), stubble burning (SB), or stubble left standing (SS), and continuous winter wheat with stubble burned and moldboard plowed (CONV). Treatments within each year with the same letters are not statistically different, $P=0.05$, Tukey's mean separation test. nia disease or inoculum. Rhizoctonia produces inoculum and survives in the roots rather than the crown, so mechanical removal of straw or burning will not reduce inoculum. In addition, burning does not heat the soil to lethal temperatures due to the thermal buffering capacity of the soil. For example, in a bluegrass burning trial in eastern Washington, the soil temperature 1 to $3 \mathrm{~cm}$ deep did not change, although the soil surface reached $240^{\circ} \mathrm{C}(14)$.

We did not detect significant levels of Fusarium crown rot in winter wheat in these experiments. This disease is exacerbated by plant water stress $(6,22)$, often triggered by early fall planting and excessive N. Irrigation probably masked the disease symptoms, even though the pathogen is present in soils in this region, and probably caused latent infections in our experiment. However, based on the soil DNA, the highest levels of $F$. pseudograminearum were observed in the treatments with standing stubble and mechanical removal treatments, compared to the continuous burn and plow and stubble burned treatments, especially by year 3 . In the burn and plow treatment with a moldboard plow, the old crowns were inverted and mixed into the soil, where the residue quickly decays. This is consistent with literature showing higher levels of Fusarium crown rot in no-till systems with high levels of residue compared to conventionally tilled systems (2,32). Previous studies have shown that $F$. pseudograminearum survives primarily as mycelium in the crowns (13), in contrast to F. culmorum which survives as chlamydospores formed from macroconidia in the soil. We consistently found lower levels of DNA of $F$. culmorum in the soil compared to DNA of F. pseudograminearum. Previous surveys in the mid-1990s (32) showed that F. pseudograminearum was the predominant species in the lower precipitation winter wheat-summer fallow areas of eastern Washington and north-central Oregon, compared to F. culmorum, which was more predominant in the higher precipitation areas with continuous annual cropping.

The root lesion nematode, $P$. neglectus, is widely distributed in the dryland areas of the Pacific Northwest, and can cause significant yield losses based on experiments with nematicides and resistant varieties (36). We found the highest concentration of DNA in the continuous winter wheat with burning and plowing, demonstrating that tillage had a minimal effect on these nematodes. Although $P$. neglectus has a wide host range, some crops, such as pea, lentil (Lens culinaris Medik.), and some cultivars of canola, result in less nematode reproduction (37). Barley is also a less conducive host for nematode reproduction (37), and is less impacted by nematode infection (33). The canola and barley in the rotation may have reduced the populations of $P$. neglectus compared to a 
monoculture of wheat, which is highly susceptible to the nematode infection and reproduction.

Although canola was not a focus of this paper, we did observe major disease problems that could be a limiting factor in canola production. Winter canola was killed in the fall in 5 of 6 years due to a combination of cold air temperatures and soilborne plant pathogens in the fall. To survive the winter, the healthy plant must form a rosette, and hence must be planted as early as possible. In 2002, winter canola was planted on 27 August and irrigated. A good stand was established by mid-September, but barley volunteers from the previous crop were also established. The barley was controlled with the grass weed herbicide established canola began to die in the field. Isolation and greenhouse testing verified Assure II (quizalofop). After 2 weeks, the that the pathogen was $R$. solani AG-2-1 (23), which causes postemergence damping-off and wirestem of canola and other brassicas $(15,40)$. This disease was probably exacerbated by the green-bridge effect of killing barley within the crop (34).

Cropping systems have a changing dynamic of disease and soilborne pathogens that are influenced by tillage practices, rotation crops, and cultural methods such as residue management. This 6-year study has demonstrated the complex interactions that occur, where one disease may be of primary importance, even though other diseases are present. Although we expected Rhizoctonia root rot to be a major limitation in a no-till system, take-all in the burn and plow monoculture winter wheat system turned out to be the greatest constraint to plant health. Although Rhizoctonia DNA concentrations in the soil were higher in the no-till systems, no major yield losses occurred $(29,41)$, possibly because of the compensatory effect of adequate water or some unknown microbial suppression. However, economics will play the greatest role in farmers' acceptance of this system. During the years that this experiment was conducted, wheat prices were low, and barley and canola prices even lower, and all crops in the rotations had negative net economic returns $(29,41)$.

\section{ACKNOWLEDGMENTS}

We thank Bruce Sauer, Harry Schafer, Steve Schofstoll, Timothy Smith, Brian Fode, Karen Adams, and Rebecca Flanagan for their excellent technical assistance. Funding for the experiment was provided by the USDA-ARS, WSU, Washington Wheat Commission, the Columbia Plateau $\mathrm{PM}_{10}$ Project, the Solutions to Economic and Environmental Problems (STEEP) Project, and the Washington Department of Ecology.

\section{LITERATURE CITED}

1. Anonymous. 2008. Washington statistics. USDA-National Agricultural Statistics Service, Washington, DC.

2. Bailey, K. L., Gossen, B. D., Lafond, G. P., Watson, P. R., and Derksen, D. A. 2001. Effect of tillage and crop rotation on root and foliar diseases of wheat and pea in Saskatchewan from 1991-1998: Univariate and multivariate analyses. Can. J. Plant Sci. 81:789-803.

3. Baker, C. J., Saxton, K. E., and Ritchie, W. R. 1996. No-tillage seeding: Science and practice. CAB International, Cambridge, UK.

4. Cook, R. J. 1981. The influence of rotation crops on take-all decline phenomenon caused by Gaeumannomyces graminis var. tritici, biological control. Phytopathology 71:189-192.

5. Cook, R. J., and Haglund, W. A. 1991. Wheat yield depression associated with conservation tillage caused by root pathogens in the soil not phytotoxins from straw. Soil Biol. Biochem. 23:1125-1132.

6. Cook, R. J., and Papendick, R. I. 1972. Influence of water potential of soils and plants on root disease (fungi). Annu. Rev. Phytopathol. 10:349-374.

Fig. 11. Percentage of seminal roots with symptoms of Rhizoctonia in winter wheat seedlings in April grown in four crop rotation/residue management treatments: winter wheat-spring barley-canola no-till rotation with mechanical stubble removal (MR), stubble burning (SB), or stubble left standing (SS), and continuous winter wheat with stubble burned and moldboard plowed (CONV). Treatments within each year with the same letters are not statistically different, $P=0.05$, Tukey's mean separation test.

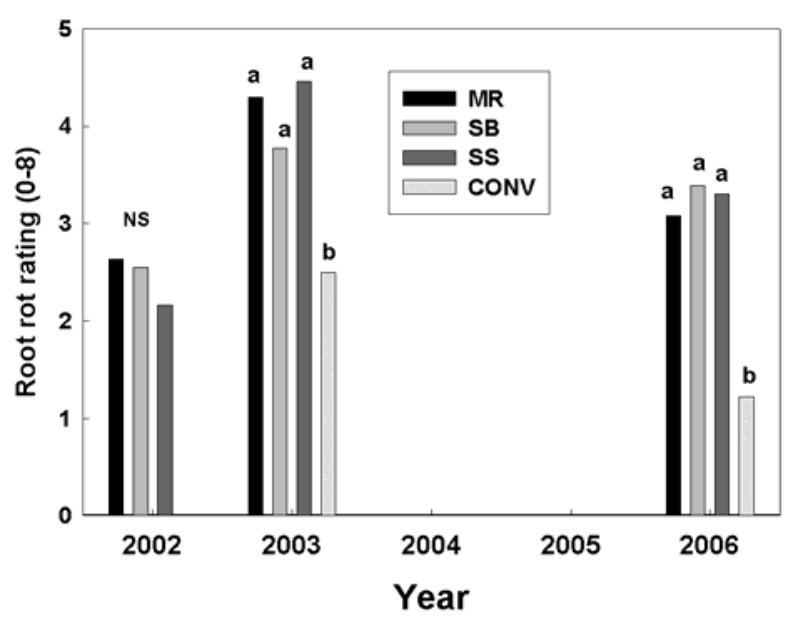

Fig. 12. Rhizoctonia root rot rating of winter wheat seedlings in April grown in four crop rotation/residue management treatments: winter wheat-spring barley-canola no-till rotation with mechanical stubble removal (MR), stubble burning (SB), or stubble left standing (SS), and continuous winter wheat with stubble burned and moldboard plowed (CONV). Treatments within each year with the same letters are not statistically different, $P=0.05$, Kruskal-Wallis mean separation test. Data were not taken in 2004 and 2005.
7. Cook, R. J., Schillinger, W. F., and Christensen, N. W. 2002. Rhizoctonia root rot and wheat take-all in diverse direct seed cropping systems. Can. J. Plant Pathol. 24:349-358.

8. Cook, R. J., and Veseth, R. J. 1991. Wheat Health Management. American Phytopathological Society, St. Paul, MN.

9. Donaldson, E., Schillinger, W. F., and Dofing, S. M. 2001. Straw production and grain yield relationships in winter wheat. Crop Sci. 41:100-106.

10. Guy, S. O., and Gareau, R. M. 1998. Crop rotation, residue durability, and nitrogen fertilizer effects on winter wheat production. J. Prod. Agric. 11:457-461.

11. Hornby, D. 1983. Suppressive soils. Annu. Rev. Phytopathol. 21:65-85.

12. Hornby, D. 1998. Take-All of Cereals: A Regional Perspective. CAB International, Wallingford, UK.

13. Inglis, D. A., and Cook, R. J. 1986. Persistence of chlamydospores of Fusarium culmorum in wheat field soils of eastern Washington. Phytopathology 76:1205-1208.

14. Johnston, W. J., Golob, C. T., Sitton, J. W., and Schultz, T. R. 1996. Effect of temperature and postharvest field burning of Kentucky bluegrass on germination of sclerotia of Claviceps purpurea. Plant Dis. 80:766-768. tonia solani damping-off and root rot in oil-
15. Kataria, H. R., and Verma, P. R. 1992. Rhizoc- 
seed rape and canola. Crop Prot. 11:8-13.

16. Kim, D.-S., Cook, R. J., and Weller, D. M. 1997. Bacillus sp. L324-92 for biological control of three root diseases of wheat grown with reduced tillage. Phytopathology 87:551-558

17. MacNish, G. C. 1985 Methods of reducing rhizoctonia patch of cereals in Western Australia. Plant Pathol. 34:175-181.

18. McSpadden Gardener, B. B., and Weller, D. M. 2001. Changes in populations of rhizosphere bacteria associated with take all of wheat. Appl. Environ. Microbiol. 67:4414-4425.

19. Moore, K. J., and Cook, R. J. 1984. Increased take-all of wheat with direct drilling in the Pacific Northwest. Phytopathology 74:10441049.

20. Ophel-Keller, K., McKay, A., Hartley, D., Herdina, and Curran, J. 2008. Development of a routine DNA-based testing service for soilborne diseases in Australia. Australas. Plant Pathol. 37:243-253.

21. Papendick, R. I. 2004. Farming with the Wind II: Wind Erosion and Air Quality Control on the Columbia Plateau and Columbia Basin. Special Report by the Columbia Plateau $\mathrm{PM}_{10}$ Project Rep. XB 1042. Washington Agric. Exp. Stn., Pullman.

22. Papendick, R. I., and Cook, R. J. 1974. Plant water stress and development of Fusarium [roseum] foot rot in wheat subjected to different cultural practices. Phytopathology 64:358363.

23. Paulitz, T. C., Okubara, P. A., and Schillinger, W. F. 2006. First report of damping-off of canola caused by Rhizoctonia solani AG 2-1 in Washington State. Plant Dis. 90:829.

24. Pumphrey, F. V., Wilkins, D. E., Hane, D. C., and Smiley, R. W. 1987. Influence of tillage and nitrogen fertilizer on Rhizoctonia root rot (bare patch) of winter wheat. Plant Dis.
71:125-127.

25. Raaijmakers, J. M., Bonsall, R. F., and Weller, D. M. 1999. Effect of population density of Pseudomonas fluorescens on production of 2,4-diacetylphloroglucinol in the rhizosphere of wheat. Phytopathology 89:470-475.

26. Raaijmakers, J. M., and Weller, D. M. 1998. Natural plant protection by 2,4diacetylphloroglucinol-producing Pseudomonas spp. in take-all decline soils. Mol. PlantMicrobe Interact. 11:144-152.

27. Rovira, A. D. 1986. Influence of crop rotation and tillage on Rhizoctonia bare patch of wheat. Phytopathology 76:669-673.

28. Schillinger, W. F., Smith, T. A., and Schafer, H. L. 2008. Chaff and straw spreader for a plot combine. Agron. J. 100:398-399.

29. Schillinger, W. F., Young, D. L., Kennedy, A. C., and Paulitz, T. C. 2010. Diverse no-till irrigated crop rotations instead of burning and plowing continuous wheat. Field Crops Res. 115:39-49.

30. Schroeder, K. L., and Paulitz, T. C. 2006. Root diseases of wheat and barley during the transition from conventional tillage to direct seeding. Plant Dis. 90:1247-1253.

31. Schwartz, J., and Neas, L. M. 2000. Fine particles are more strongly associated than coarse particles with acute respiratory health effects in schoolchildren. Epidemiology 11:610.

32. Smiley, R. W., Collins, H. P., and Rasmussen, P. E. 1996. Diseases of wheat in long-term agronomic experiments at Pendleton, Oregon. Plant Dis. 80:813-820.

33. Smiley, R. W., and Machado, S. 2009. Pratylenchus neglectus reduces yield of winter wheat in dryland cropping systems. Plant Dis. 93:263-271.

34. Smiley, R. W., Ogg, A. G., and Cook, R. J.
1992. Influence of glyphosate on Rhizoctonia root rot, growth, and yield of barley. Plant Dis. 76:937-942.

35. Smiley, R. W., and Patterson, L.-M. 1996. Pathogenic fungi associated with Fusarium foot rot of winter wheat in the semiarid Pacific Northwest. Plant Dis. 80:944-949.

36. Smiley, R. W., Whittaker, R. G., Gourlie, J. A., and Easley, S. A. 2005. Suppression of wheat growth and yield by Pratylenchus neglectus in the Pacific Northwest. Plant Dis. 89:958-968.

37. Taylor, S. P., Hollaway, G. J., and Hunt, C. H. 2000. Effect of field crops on population densities of Pratylenchus neglectus and P. thorne in southeastern Australia. 1. P. neglectus. J. Nematol. 32:591-599.

38. Weller, D. M., Cook, R. J., MacNish, G., Bassett, E. N., Powelson, R. L., and Petersen, R. R. 1986. Rhizoctonia root rot of small grains favored by reduced tillage in the Pacific Northwest. Plant Dis. 70:70-73.

39. Weller, D. M., Raaijmakers, J. M., McSpadden-Gardener, B. B., and Thomashow, L. S. 2002. Microbial populations responsible for specific soil suppressiveness to plant pathogens. Annu. Rev. Phytopathol. 40:309-348.

40. Yibarek, S. M., Verma, P. R., and Morrall, R A. A. 1987. Anastomosis groups, pathogenicity, and specificity of Rhizoctonia solani isolates from seedling and adult rapeseed/canola plants and soils in Saskatchewan. Can. J. Plant Pathol. 9:6-13.

41. Zaikin A. A., Young, D. L., and Schillinger, W. F. 2008. Economics of an irrigated no-till crop rotation with alternative stubble management practices versus continuous irrigated winter wheat with burning and plowing of stubble. Washington State Univ. Ext. Bull. EB2029E. Online: http://farm.mngt.wsu.edu/nonirr.htm. 